\title{
Drug interactions between herbal medicines and oral contraceptives
}

\author{
Interações medicamentosas entre fitoterápicos e contraceptivos orais \\ Interaciones farmacológicas entre medicamentos a base de plantas y anticonceptivos orales
}

\begin{abstract}
The use of herbal medicines has grown considerably in recent years, due to the erroneous thought that products of plant origin are harmless, and therefore do not cause adverse effects or have drug interactions. The use of these drugs with oral contraceptives can bring risks to patients. The potential negative clinical effects that can be caused by these drug interactions must be emphasized to prevent risks and ensure the effectiveness of this contraceptive method that is one of the most used by women seeking to prevent pregnancy. The users of herbal medicines usually believe that herbal medicine is a therapeutic alternative free of adverse effects and/or incapable of causing drug interactions, but herbal medicines are composed of several chemical compounds, which, in turn, may be responsible for antagonistic and/or synergistic effects with other drugs. The main interactions that can occur with contraceptives are with popularly used herbal medicines such as licorice, alfalfa, cannabis, cimicifuga, St. John's wort, ginseng, kava-kava, saw palmetto, sene, and soy. The herbal medicines have several chemical compounds, among which we highlight the secondary metabolites, responsible for the pharmacological actions and mechanism of action of drug interactions, which are often similar in plants that have in their composition the same metabolites, as in the case of saponins and isoflavones that reduce the speed of biotransformation of oral contraceptives.
\end{abstract}

Keywords: Oral contraceptives; Drug interactions; Phytotherapeutic drugs.

\section{Resumo}

O uso de fitoterápicos cresceu consideravelmente nos últimos anos, devido ao pensamento errôneo de que os produtos de origens vegetais não trazem danos, portanto não causam efeitos adversos e nem possuem interações medicamentosas. $\mathrm{O}$ uso desses medicamentos com os contraceptivos orais pode trazer riscos às pacientes, portanto, os potenciais efeitos clínicos negativos que podem ser causados por essas interações medicamentosas devem ser enfatizados para prevenir riscos e garantir a eficácia desse método contraceptivo que é um dos mais utilizados por mulheres que buscam prevenir a gravidez. As usuárias de fitoterápicos costumam acreditar que a fitoterapia é uma alternativa terapêutica isenta de efeitos adversos e/ou incapazes de causar interações medicamentosas, sendo os fitoterápicos constituídos de vários compostos químicos, que por sua vez podem ser responsáveis por efeitos antagônicos e/ou sinérgicos com outros medicamentos. As principais interações que podem ocorrer com os contraceptivos são com os fitoterápicos popularmente utilizados como o alcaçuz, alfafa, cannabis, cimicífuga, erva de São João, ginseng, kava-kava, saw palmetto, sene e soja. Os fitoterápicos apresentam diversos compostos químicos, dentre eles destacam-se os metabólitos secundários, responsáveis pelas ações farmacológicas e mecanismo de ação das interações medicamentosas, que muitas vezes são similares em plantas que possuem em sua composição os mesmos metabólitos, como no caso das saponinas e isoflavonas que reduzem a velocidade de biotransformação dos anticoncepcionais orais.

Palavras-chave: Contraceptivos orais; Interações medicamentosas; Medicamentos fitoterápicos. 


\begin{abstract}
Resumen
El uso de los medicamentos a base de plantas ha crecido considerablemente en los últimos años, debido al pensamiento erróneo de que los productos de origen vegetal no traen perjuicios, por lo que no causan efectos adversos y tampoco tienen interacciones farmacológicas. El uso de estos fármacos con los anticonceptivos orales puede traer riesgos a las pacientes, por lo tanto, se debe enfatizar los potenciales efectos clínicos negativos que pueden ser causados por estas interacciones farmacológicas para prevenir riesgos y asegurar la efectividad de este método anticonceptivo que es uno de los más utilizados por las mujeres que buscan prevenir el embarazo. Los usuarios de fitoterápicos suelen creer que la fitoterapia es una alternativa terapéutica libre de efectos adversos y/o incapaz de provocar interacciones farmacológicas, ya que los fitoterápicos están formados por varios compuestos químicos, que a su vez pueden ser responsables de efectos antagónicos y/o sinérgicos con otros fármacos. Las principales interacciones que pueden producirse con los anticonceptivos son con las hierbas medicinales de uso popular, como el regaliz, la alfalfa, el cannabis, la cimífuga, la hierba de San Juan, el ginseng, el kavakava, la palma enana americana, el sene y la soja. Los medicamentos a base de plantas tienen varios compuestos químicos, entre los que destacan los metabolitos secundarios, responsables de las acciones farmacológicas y del mecanismo de acción de las interacciones de los medicamentos, que suelen ser similares en las plantas que tienen en su composición los mismos metabolitos, como es el caso de las saponinas y las isoflavonas que reducen la velocidad de biotransformación de los anticonceptivos orales.
\end{abstract}

Palabras clave: Anticonceptivos orales; Interacciones con otros medicamentos; Medicamentos fitoterápicos.

\title{
1. Introduction
}

The use of herbal medicines has grown considerably in recent years, due to the erroneous thought that products of plant origin do not cause harm, the famous: "what is natural is not harmful", therefore they do not cause adverse effects or have drug interactions, but the herbal medicines are composed of several chemical compounds, which in turn may be responsible for antagonistic and/or synergistic effects with other drugs (Brazil, 2004, 2006).

Phytotherapy is an integrative therapy and has been implemented in Brazil through primary health care programs for its great efficacy and low cost. The concomitant administration of herbal medicines with oral hormonal contraceptives can significantly alter the plasma concentrations of contraceptives, changing their efficacy and/or safety profile. (Izzo \& Ernst, 2009; Brasil, 2015).

Interactions can occur with plants used for the preparation of teas, home-made syrups, and herbal medicines. These plants are generally used for self-care, leading to the habit of patients not informing health professionals about their use. In addition, this use also goes unnoticed by professionals, who do not usually investigate the patient's complete history during the anamnesis. (Barnes, 2003; Brazil, 2010).

The use of herbal medicines with oral contraceptives can bring risks to patients, therefore, the potential negative clinical effects that can be caused by these drug interactions should be emphasized to prevent risks and ensure the effectiveness of this contraceptive method that is one of the most used by women seeking to prevent pregnancy (Silva \& Rocha, 2013).

Hormonal contraceptives can be divided into simple or combined oral contraceptives. They are used to inhibit the secretion of follicle-stimulating hormone and luteinizing hormone, which can thicken the cervical mucus and hinder the passage of sperm. The adherence of this therapeutic class is directly related to the benefits they provide, such as pregnancy prevention, menstrual cycle regularization, colic reduction, acne, anemia, and ectopic pregnancy (Brito et al., 2011; Almeida \& Assis, 2017).

The change in the profile of women assuming their role as the protagonist of their lives over the past decades, especially in relation to sexuality, way of thinking, and the purpose of life in modern times, has led to the use of oral hormonal contraceptives being increasingly used. Among them, the most common, offered by SUS are oral contraceptives such as, simple oral contraceptives (minipills) and combined oral contraceptives. Approximately $18 \%$ of women, in a stable relationship or not, use these methods in developed countries, while in developing countries this number reaches about $75 \%$. Therefore, the objective of this literature review is to elucidate drug interactions between oral contraceptives and herbal medicines, and that their concomitant use can cause an undesired pregnancy. (Bahamondes et al., 2011). 


\section{Methodology}

This is an integrative literature review through scientific studies on oral hormonal contraceptives and their main drug interactions with herbal medicines and medicinal plants, through their concomitant use, carried out in the SciELO (ScientificElectronic Library onLine) and Google Academic databases by articles, theses, dissertations, the following key words were employed: oral contraceptives, herbal medicines, mechanism of action, drug interactions. Some parameters were established for the research, such as: be related to the theme; definition of inclusion and exclusion criteria; identification and categorization of articles; analysis and interpretation of results and presentation of conclusion/synthesis.

A total of 70 articles were selected by inclusion and exclusion criteria: 11 articles related to oral hormonal contraceptives and 59 articles related to herbal medicines and drug interactions. The aim was to understand the main drug interactions between herbal medicines and oral hormonal contraceptives, highlighting the awareness of the correct and rational use and the importance of the knowledge of these interactions to prevent risks related to the safety and/or efficacy profiles of this therapeutic class.

Figure 1. Reference Article Selection Process.

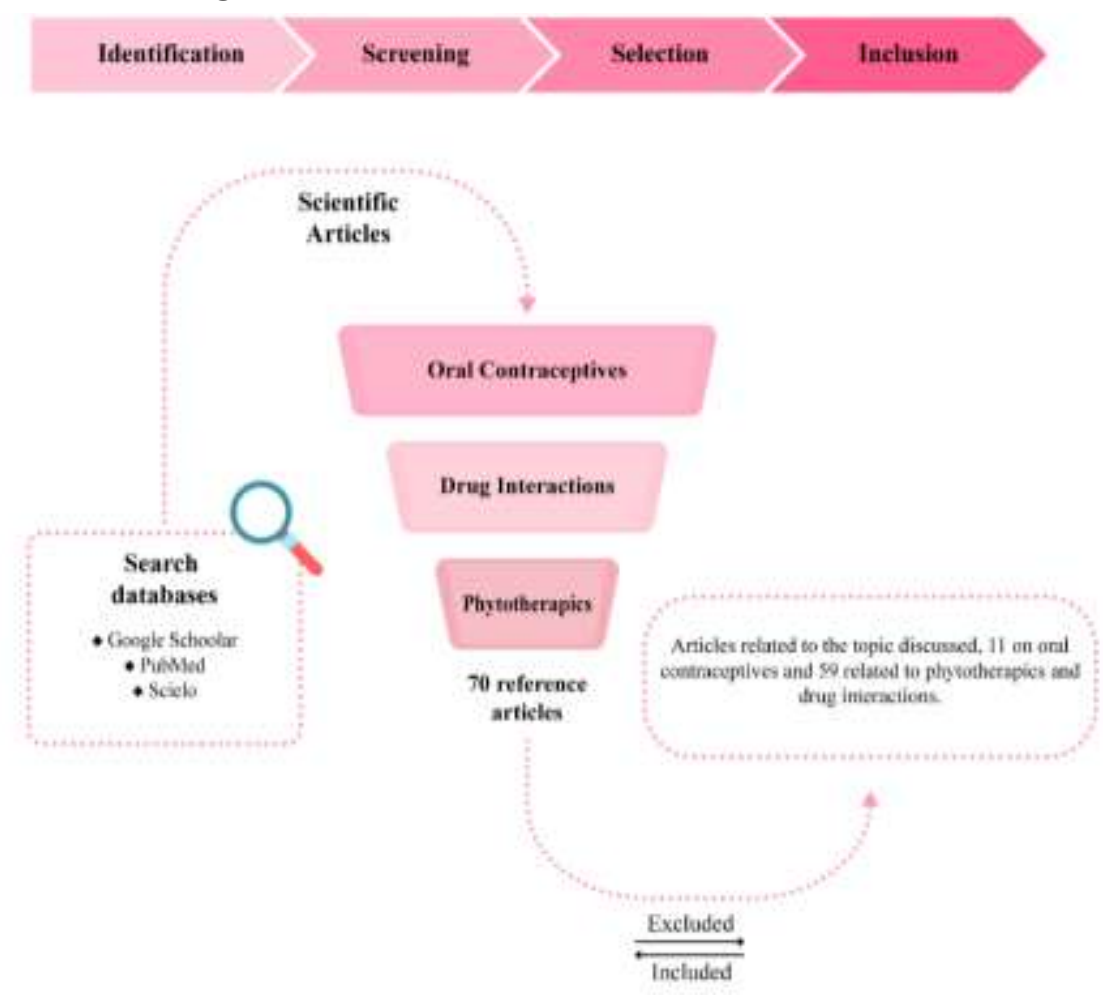

Source: Authors.

\section{Simple Oral Contraceptives}

The simple oral contraceptives, commonly known as mini-pills, are based on progesterone (female sex hormone secreted by the body) produced from cholesterol, considered a precursor of androgens, estrogens and adrenocorticoids. Despite their low efficacy, they promote thickening of the cervical mucus, hindering sperm penetration. In addition, they have beneficial effects in reducing menstrual cramps, flow reduction, premenstrual symptoms, and breast tension. Furthermore, it has no correlation with increased risk for malignant diseases, and adverse effects are rarely reported (Rathke et al., 2001). 


\section{Combined Oral Contraceptives}

Combined oral contraceptives are based on progesterone and estrogen. Progesterone inhibits the secretion of the luteinizing hormone ( $\mathrm{LH}$ ) and, as previously mentioned, prevents ovulation and stimulates the production of cervical mucus, hindering sperm penetration and estrogen inhibits the secretion of the follicle-stimulating hormone (FSH) (N. C. de S. Silva et al., 2017).

They are classified as monophasic, biphasic, and triphasic and are considered to be quite effective; in cases of intercurrent diseases or drug or non-drug interactions, their effectiveness may be reduced. The control of FSH and LH depends basically on the hypothalamic gonadotropin-releasing hormone ( $\mathrm{GnRH})$. FSH and LH still act together with the ovarian steroids, estrogen and progesterone, which in constant balance are important for the ovulation process and the negative and positive feedback process (N. C. de S. Silva et al., 2017).

The negative feedback that female sex hormones exert on the hypothalamic-pituitary base occurs both in the pituitary gland and in the hypothalamus, promoting GnRH inhibition. In the positive feedback, during the pre-ovulatory period, estrogens exert a GnRH secretion mechanism, resulting in ovulation. Estrogens also increase the evidence of GnRH receptors in the pituitary gland, assisting with the secretory peak of $\mathrm{LH}$, at the time of ovulation. In most combination formulations the estrogen is ethinyl estradiol, but in some formulations it is replaced by mestranol. On the other hand, the progestogen can be norestosterone, levonorgestrel, ethinodiol, desosgestrel or gestodene. The latter two being the most potent (de Silva et al., 2017).

Figure 2. Composition and mechanism of action of oral contraceptives.

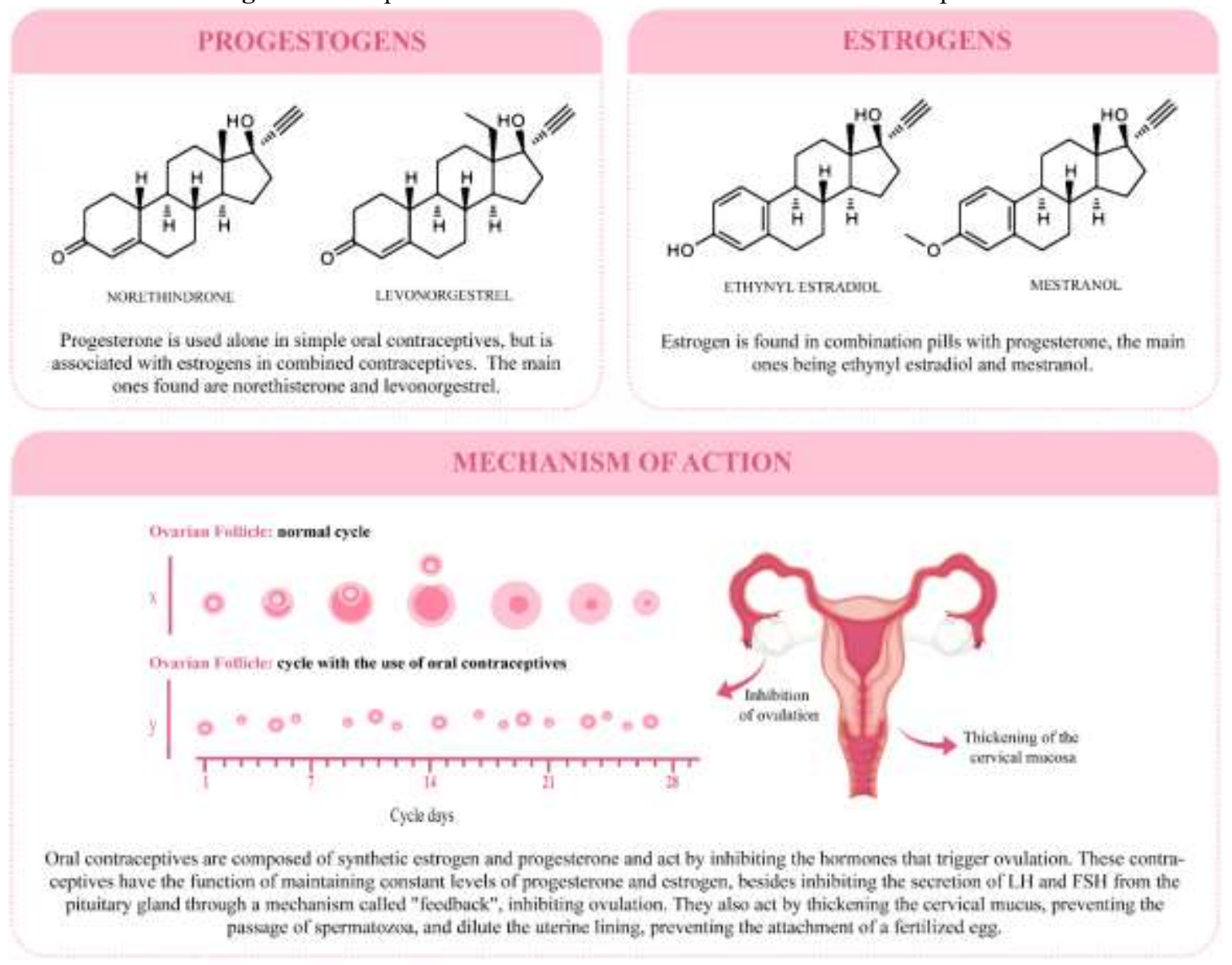

Source: Authors. 


\section{Secondary Metabolites}

Secondary metabolites are also called natural products or secondary products and have specific actions, but evidence shows that they are unrelated to the growth and development of plants. They are divided into three groups: terpenes, phenolic compounds, and nitrogenous compounds. As they present great therapeutic effects for humans they are frequently used by pharmaceutical industries for drug design (Naczk, 2003; Taiz; Shahidi, Ho, 2005; Taiz, Zeiger, 2006).

Figure 3. Classification of plant secondary metabolites.

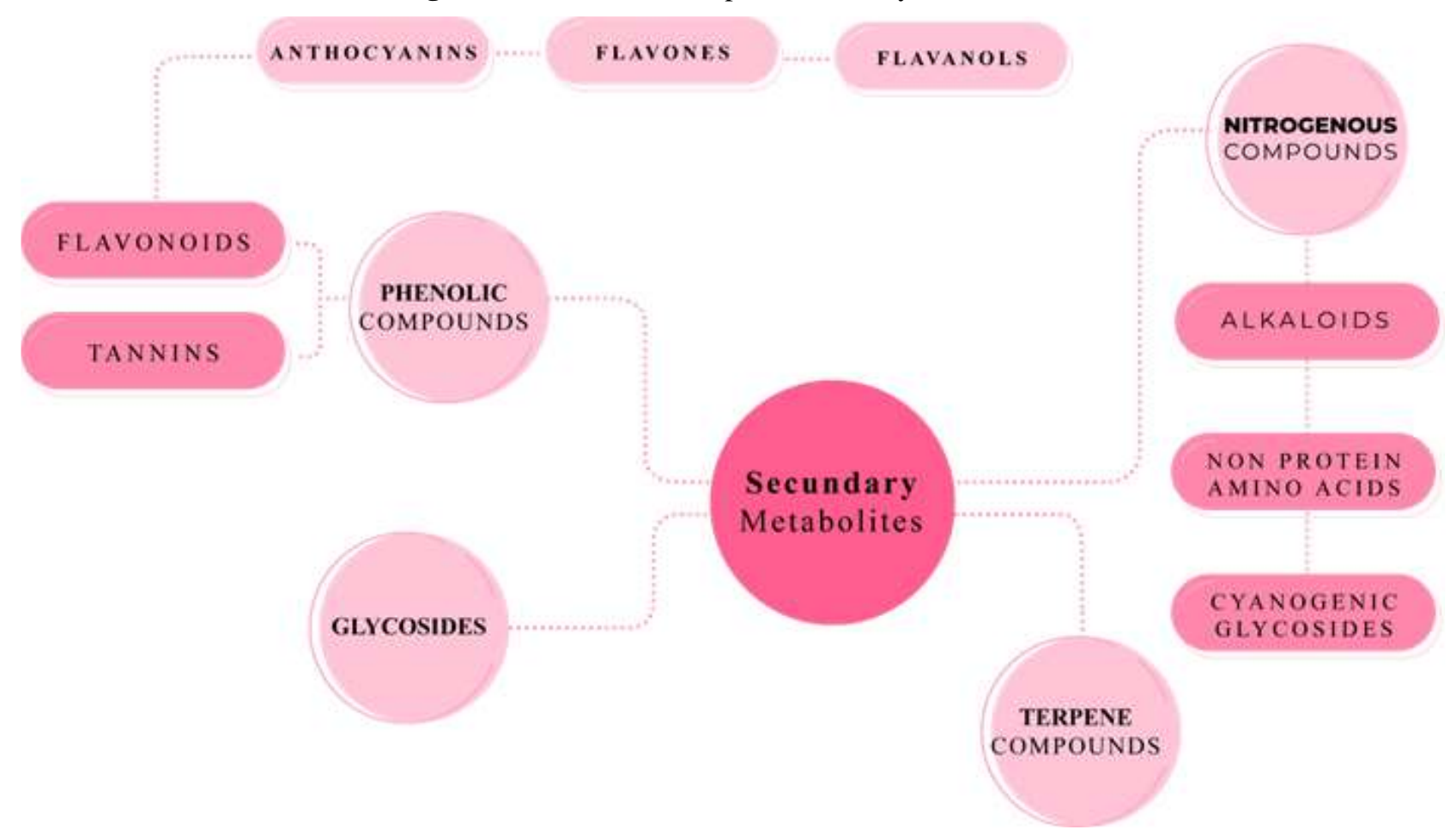

Source: Authors.

\section{Phytotherapeutic Medicines}

Herbal medicines have curative, prophylactic or palliative purposes, obtained from active vegetable raw materials, but cannot be isolated substances. They are divided into simple, when the active is obtained only from a single medicinal plant species or compound, when the active is obtained from more than one plant species (Brazil, 2014; CRF-SP, 2019).

A science inherited from cultural beliefs and traditions, the use of medicinal plants with healing properties is commonly consumed by the population to fight the flu, menstrual cramps, constipation, menopausal symptoms, coughs, etc., intensifying self-medication, which is commonly practiced by Brazilians who seek affordable non-prescription drugs, since $75 \%$ do not have health insurance (Brazil, 2001).

The easy access to medicinal plants corroborates the belief that "natural does no harm", thus, the herbal medicines or derivatives such as infusion, syrups, tablets, essential oils, ointments, pastes, creams and gels, are usually consumed without concern about their drug interactions, toxicity and adverse reactions. Aiming at drug interactions, we have the interactions of oral contraceptives with herbal medicines, little known by the women who make concomitant use of these medicines (Brazil, 2004). 


\section{Main herbal medicines that interact with oral contraceptives}

Therefore, the use of herbal medicines, with the high number of women who make concomitant use with oral hormonal contraceptives, may decrease the absorption, efficacy and safety of the method. Plants known and used as herbal medicines, supposedly harmless, cause interactions often unknown by the group that uses them. The main herbal medicines that have interactions with oral hormonal contraceptives, were highlighted in this review (Table 1) (Silva \& Rocha, 2013).

Table 1: Herbal Medications that interact with oral contraceptives.

\begin{tabular}{|c|c|c|c|c|c|}
\hline $\begin{array}{l}\text { POPULAR } \\
\text { NAME }\end{array}$ & $\begin{array}{l}\text { SCIENTIFIC } \\
\text { NAME }\end{array}$ & $\begin{array}{l}\text { SECONDARY } \\
\text { METABOLITES }\end{array}$ & $\begin{array}{l}\text { THERAPEUTIC } \\
\text { INDICATION }\end{array}$ & MECHANISM OF ACTION & REFERENCES \\
\hline Licorice & $\begin{array}{l}\text { Glycyrrhiza } \\
\text { glabra }\end{array}$ & $\begin{array}{c}\text { Saponin, triterpenes, } \\
\text { isoflavone }\end{array}$ & $\begin{array}{c}\text { Anti-inflammatory, } \\
\text { antioxidant, anti-allergic, } \\
\text { laxative, expectorant, } \\
\text { detoxifier }\end{array}$ & $\begin{array}{l}\text { Pharmacodynamic interaction } \\
\text { through competition for the } \\
\text { estrogen receptor binding site }\end{array}$ & $\begin{array}{c}\text { Nassiri Asl \& } \\
\text { Hosseinzadeh, 2008 } \\
\text { Silva \& Rocha, 2013 }\end{array}$ \\
\hline Alfafa & Medicago sativa & Isoflavone & $\begin{array}{l}\text { Anxiolytic, constipation } \\
\text { and reduction of fluid } \\
\text { retention }\end{array}$ & $\begin{array}{l}\text { Pharmacodynamic interaction } \\
\text { through competition for the } \\
\text { estrogen receptor binding site }\end{array}$ & $\begin{array}{c}\text { Lim, 2016, } \\
\text { N. C. de S. Silva et } \\
\text { al., } 2017\end{array}$ \\
\hline $\begin{array}{l}\text { Marijuana, } \\
\text { Cannabis }\end{array}$ & Cannabis sativa & $\begin{array}{l}\text { Triterpenes, flavonoids } \\
\text { and alkaloids }\end{array}$ & $\begin{array}{l}\text { Anticonvulsant, anxiolytic, } \\
\text { sedative, antidepressant, } \\
\text { and anticarcinogenic }\end{array}$ & $\begin{array}{c}\text { Induction of cytochrome P450, } \\
\text { specifically of the CYP3A4 } \\
\text { isoenzyme }\end{array}$ & $\begin{array}{l}\text { Lewis et al., } 2017 \\
\text { Lucas et al., 2018; } \\
\text { Souza et al., } 2021\end{array}$ \\
\hline Black Cohosh & $\begin{array}{l}\text { Cimicifuga } \\
\text { racemosa }\end{array}$ & Isoflavones & $\begin{array}{l}\text { Antioxidant and anti- } \\
\text { inflammatory }\end{array}$ & $\begin{array}{l}\text { Competition between active } \\
\text { ingredients for estrogen } \\
\text { receptors }\end{array}$ & $\begin{array}{l}\text { Wobser \& Pellegrini, } \\
2018 \\
\text { Esteves et al., } 2020\end{array}$ \\
\hline $\begin{array}{l}\text { Saint John's } \\
\text { Wort }\end{array}$ & $\begin{array}{l}\text { Hypericum } \\
\text { perforatum }\end{array}$ & $\begin{array}{l}\text { Anthraquinones/ } \\
\text { naphthodiantrones, } \\
\text { floroglucinol derivatives, } \\
\text { flavonoids, biflavones } \\
\text { and xanthones }\end{array}$ & $\begin{array}{c}\text { Anxiolytic, } \\
\text { nephroprotective, } \\
\text { antioxidant, antifungal }\end{array}$ & $\begin{array}{l}\text { Induction of cytochrome P450, } \\
\text { specifically of the CYP3A4 } \\
\text { isoenzyme }\end{array}$ & $\begin{array}{l}\text { Greeson et al., 2001 } \\
\text { Schwarz et al., 2003; } \\
\text { Murphy et al., 2005). }\end{array}$ \\
\hline Ginseng & Panax ginseng & $\begin{array}{c}\text { Triterpenes, steroids, } \\
\text { saponins and flavonoids }\end{array}$ & $\begin{array}{l}\text { Increased concentration, } \\
\text { reduced stress, reduced } \\
\text { physical and mental fatigue }\end{array}$ & $\begin{array}{c}\text { Induction of cytochrome P450, } \\
\text { specifically of the CYP3A4 } \\
\text { isoenzyme }\end{array}$ & $\begin{array}{c}\text { Waterman, 1992; } \\
\text { Williamson, 2001; } \\
\text { Simões \& Schenkel, } \\
\text { 2002; } \\
\text { Fernandes, } 2011\end{array}$ \\
\hline Kava-Kava & Piper methysticum & $\begin{array}{c}\text { Kavalactones, } \\
\text { alkavalones, alkaloids } \\
\text { and chalcones } \\
\text { (flavocavains) }\end{array}$ & Anxiolytic and insomnia & Inhibition of CYP3A4 & $\begin{array}{c}\text { Bilia et al., 2002; } \\
\text { Cordeiro et al., 2005; } \\
\text { Unger et al., 2002; } \\
\text { Zou et al., 2004; } \\
\text { Coulter et al., 2007 } \\
\end{array}$ \\
\hline Saw Palmetto & Serenoa repens & $\begin{array}{c}\text { Isoflavone (flavonoids), } \\
\text { tannins }\end{array}$ & $\begin{array}{l}\text { Diuretic, expectorant, } \\
\text { sedative, and treatment for } \\
\text { benign prostatic } \\
\text { hypertrophy }\end{array}$ & $\begin{array}{l}\text { Pharmacodynamic interaction } \\
\text { through competition for the } \\
\text { estrogen receptor binding site }\end{array}$ & $\begin{array}{c}\text { Dhariwala \& } \\
\text { Ravikumar, 2019; } \\
\text { Esteves et al., } 2020\end{array}$ \\
\hline Sene & $\begin{array}{c}\text { Cassia } \\
\text { angustifolia }\end{array}$ & $\begin{array}{l}\text { Alkaloids and phenolic } \\
\text { compounds, } \\
\text { anthraquinones, } \\
\text { flavonoids, coumarins, } \\
\text { flavonoids, saponins, and } \\
\text { tannins }\end{array}$ & Laxative & $\begin{array}{l}\text { Decreased intestinal transit, } \\
\text { therefore decreased absorption } \\
\text { of oral contraceptives }\end{array}$ & $\begin{array}{c}\text { Rodrigues et al., } \\
\text { 2009; Organization, } \\
2009\end{array}$ \\
\hline Soybeans & Glycine $\max$ & Isoflavones & $\begin{array}{l}\text { Prevention of post- } \\
\text { menopausal osteoporosis, } \\
\text { heart disease and cancer }\end{array}$ & $\begin{array}{l}\text { Pharmacodynamic interaction } \\
\text { through competition for the } \\
\text { estrogen receptor binding site }\end{array}$ & $\begin{array}{c}\text { Bortolini, 2009; } \\
\text { Brasil, 2016; N. C. de } \\
\text { S. Silva et al., } 2017\end{array}$ \\
\hline
\end{tabular}

Source: Authors.

The drug interactions between herbal medicines and oral contraceptives found in this literature review showed four different mechanisms of action, being the herbal medicines that have flavonoids, specifically isoflavones that in their composition are responsible for competing with contraceptives for the binding site on estrogen receptors and thus decrease the effectiveness of the drug (Nassiri Asl \& Hosseinzadeh, 2008; Bortolini, 2009; Silva \& Rocha, 2013; Lim, 2016; Brasil, 2016; N. C. de S. 
Silva et al., 2017; Wobser \& Pellegrini, 2018; Dhariwala \& Ravikumar, 2019; Esteves et al., 2020). Herbal drugs contain anthraquinones which have laxative properties and decreases the oral absorption when administered drug when take in short intervals intervals (Rodrigues et al., 2009; Organization, 2009).

The herbal medicines inducing CYP3A4 increase the speed of excretion of the contraceptives and decrease their bioavailability, in other words, the concentration in the blood is reduced as well as its effectiveness (Murphy et al., 2005; Fernandes, 2011; Souza et al., 2021). In the case of kava-kava, which is an inhibitor of CYP3A4, the mechanism of interaction is the opposite, because it reduces the speed of excretion of contraceptives and increases their circulation time and toxicity (Bilia et al., 2002; Cordeiro et al., 2005; Unger et al., 2002; Zou et al., 2004; Coulter et al., 2007).

\section{Licorice (Glycyrrhiza glabra L.):}

Glycyrrhiza glabra L. popularly known as licorice, distributed in tropical and warm-climate regions. Its leaves are pinnate with violet, axillary spike flowers. It is one of the oldest plants where its rhizome is used for pharmacological and food purposes (Vibha et al., 2009; Wittschier et al., 2009).

The pharmacological activities attributed to licorice used in medicine are: anti-inflammatory, anti-allergic, mainly in bronchitis, asthma, allergies, dermatitis and eczema, antifungal, antibacterial, anti-ulcerogenic, antitumor, antioxidant and expectorant, functions performed by the presence of glycyrrhizic acid, glycyrrhizin, isoliquiritigenin, hispaglabridin B, paratocarpin B and glabiridin. (Biondi et al., 2005; Nassiri Asl \& Hosseinzadeh, 2008).

Its main component, glycyrrhizic acid, a pentacyclic triterpenic saponin is the major component responsible for its pharmacological activities. Glabridin is the main isoflavone that gives yellow coloration of the root and contributes to its pharmacological activities. (Lim, 2016).

The saponins and isoflavones present in licorice reduce the effectiveness of oral contraceptives by decreasing their absorption, as does alfalfa, as they have interaction with estrogen receptors, reducing safety, increasing toxicity and side effects (Vincent \& Fitzpatrick, 2000; Silva \& Rocha, 2013).

\section{Alfalfa (Medicago sativa $\mathrm{L}$. .):}

Medicago sativa, popularly known as Alfalfa, is a plant belonging to the legume family with a sub-family in the Papilonoideae, originated from the southern Caucasus and Asia minor presents among its compounds: tannins, saponosides, phytosterols, isoflavones, coumestrol traces of alkaloids and phospholipids with high levels of isoflavones and saponins (Lemus Rodríguez et al 2003; Cook, B G et al, 2005).

Already used for a long time by the Chinese, Medicago sativa in herbal medicine has its main indications in disorders related to menopause, gastric, rectal, nasal and capillary hemorrhages, lack of appetite, osteoporosis, anemia and fatigue (Pereira, 2015).

Its application is related to the action on estrogen receptors and its antioxidant effects, in addition, it is able to enzymatically inhibit the biotransformation of oral contraceptives, which is due to the presence of isoflavones and saponins in its compounds (Vincent \& Fitzpatrick, 2000; Lim, 2016).

With the high rate of isoflavones and saponins among the compounds present in alfalfa, and the concomitant use with contraceptives can reduce and absorption and effectiveness of these contraceptives (N. C. de S. Silva et al., 2017).

\section{Cannabis (Cannabis sativa)}

Cannabis sativa has approximately 550 chemical compounds in its composition, with 113 phytocannabinoids and 120 terpenes (Aizpurua-Olaizola et al., 2016). Terpenes, flavonoids and alkaloids, fatty acids, cannabinoids, phenols (e.g., THC), plant oils, tocopherol, carotenes, and other phenolic compounds stand out (Lewis et al., 2017). 
In many countries there is trade in cannabis-based medicines, such as extracts, herbal products or isolated cannabinoid drugs, liquid extracts, or even in foods and capsules with standardized concentrations of CBD and THC, can be administered through inhalation, orally or sublingually. There are also cannabis vaporizers for therapeutic use with the ability to spray the dried drug or extract, which are electronically heated to decarboxylate the compound in a water vapor mixture. This route of administration presents few respiratory risks compared to combustion products, cannabis exhibits anticonvulsant anticarcinogenic, anxiolytic, sedative, and antidepressant therapeutic effects (Hanan Abramovici \& Sophie-Anne Lamour, Ph.D. and George Mammen, 2018; Souza et al., 2021).

THC and CBD are metabolically by cytochrome P450, especially by the CYP3A4 isoenzyme, undergoing hydroxylation resulting in 7-hydroxycannabidiol, followed by other metabolism steps. Competitive inhibition of CYP3A4 is responsible for the interaction between cannabis and oral contraceptives, which are also metabolized by this enzyme, reducing the safety of contraceptives and increasing adverse effects (Hanan Abramovici \& Sophie-Anne Lamour, Ph. D. and George Mammen, 2018; Lucas et al, 2018; Souza et al., 2021).

\section{Black Cohosh (Cimicifuga racemosa):}

Cimicifuga racemosa is popularly known as Black cohosh, presents in its composition biologically active substances such as the isoflavone formononetin, the isoferulic, caffeic, salicylic and fucinolic acids, fatty acids, tannins and sugars, phytosterin and resins that include triterpene glycosides of the Cimicifugae family. The mechanism of action is not yet fully elucidated, but it is believed that they act on the central nervous system, altering the serotoninergic pathway, there is also other evidence of their ability to act as an antioxidant and anti-inflammatory. One of the main therapeutic properties of cimicifuge its ability to selectively modulate estrogen receptors (Wobser \& Pellegrini, 2018).

Cimicifuga is used therapeutically to ease pre and postmenopausal symptoms and alleviate menstrual discomforts, such as cramps. In Brazil it is found in the composition of several herbal medicines such as Tepemen ${ }^{\circledR}$ (Abnat), Mencirax ${ }^{\circledR}$ (Ativus), Menocimed ${ }^{\circledR}$ (Cimed), Tensiane ${ }^{\circledR}$ (Greenfarma) and Clifemim ${ }^{\circledR}$ (Herbarium), among others (Brazil, 2006; Barnes, 2010).

A clinical study conducted by Huntley \& Ernst (2003) compared the efficacy of Black cohosh extract compared to conjugated estrogen therapy and placebo to alleviate menopausal symptoms, for this a double-blind study was conducted, there was clinical evidence that proved a significant improvement in symptoms compared to conventional treatment with the use of conjugated estrogens. Both treatments improve menopausal symptoms in women, but the Black cohosh extract has advantages because it is a natural treatment (A. G. Silva et al., 2009).

The interaction between cimicifuge and oral contraceptives occurs by the competition between the active ingredients of both for estrogen receptors, where selectively are able to suppress the secretion of LH (Esteves et al., 2020).

\section{Saint John's Wort (Hypericum perforatum L.):}

Saint John's Wort, as it is popularly known, belongs to the Guttiferae family. It presents in its chemical composition: tannins, anthraquinones/naphthodianthrones, flavonoids, floroglucinols, saponins, essential oil, resins, pectin, procyanidins, vitamin C, phytosterols, amino acids and carotenes (Greeson et al., 2001).

The main use of $H$. perforatum is its antidepressant therapeutic action, with the anthraquinone/naphthodianthrone group and floroglucinol as the main biological compounds capable of providing this effect (Bahis, 2001; Greeson et al., 2001; Rätz et al., 2001; Cordeiro et al., 2005).

Brazil has the highest rate in Latin America of people with depression, corresponding to about $5.8 \%$ of Brazilians, and this results in a huge amount of synthetic antidepressants prescribed (World Health Organization Geneva, 2017). Based on studies that prove the efficacy of $H$. perforatum for cases of mild to moderate depression, as it has a higher tolerability profile than 
synthetic antidepressants, the herb extract has become an alternative treatment adopted by many prescribers to treat the clinical picture of their patients (Bahis, 2001; Rätz et al., 2001).

The drug interaction between $\mathrm{H}$. perforatum and oral contraceptives occurs by induction of the metabolic pathway of St. John's Wort involving the cytochrome P450, more specifically the CYP3A4 isoenzyme, decreasing the effectiveness of contraceptives, and can cause bleeding and unwanted pregnancy, this interaction also occurs with emergency hormonal contraception, better known as the morning-after pill. (Hall et al, 2003; Pfrunder et al., 2003; Schwarz et al., 2003; Murphy et al., 2005).

There is a great risk for women who take oral contraceptives concomitantly with St. John's Wort, so when the administration of $H$. perforatum cannot be avoided, it is important that the prescriber or pharmacist guide patients to resort to other contraceptive methods to prevent pregnancy, suspending the use of oral contraceptives (Hall et al., 2003; Murphy et al., 2005; Farias et al., 2016; Almeida \& Assis, 2017).

Studies have reported cases of women who became pregnant due to the concomitant use of oral contraceptives and $H$. perforatum, with two cases recorded in Sweden, four in Germany, and seven in the United Kingdom. Another case was a 36year-old woman who self-medicated with St. John's Wort and a combined oral contraceptive containing ethinylestradiol/dienogest and as a result ended up becoming pregnant (Schwarz et al., 2003; Murphy et al., 2005).

The concentration of hormones such as ethinyl estradiol, norethindrone and ketodesogestrel increased with St. John's wort in three clinical trials (Hall et al., 2003; Pfrunder et al., 2003; Murphy et al., 2005) however a fourth trial demonstrated that the herb extract containing a hyperforin content does not alter plasma concentrations of oral contraceptives (Will-Shahab et al., 2009).

\section{Ginseng (Panax Ginseng)}

The root or rhizome Panax Ginseng, popularly known as ginseng, of Korean origin is a perennial plant with small white flowers (which bloom from the third year of its life cycle) and red berries (fruits), also known as "Korean ginseng" because of its origin (World Health Organization, 2002; Fernandes, 2011). It has been used in Eastern countries for over 2000 years to increase energy and immune function, and has a variety of pharmacological activities in the cardiovascular, endocrine, immune and central nervous systems (Piao et al., 2020).

The recognized main actives of ginseng are a group of 30 triterpene saponins, which vary in content and relative proportions among different ginseng species. In addition to saponins, referred to as "ginsenosides," studies show that tannins, polysaccharides, heterogeneous peptidoglycan-like polysaccharides, flavonoids, group B vitamins, and sesquiterpene essential oils have also been found in ginseng (Fernandes, 2011).

Secondary metabolites, encompass the class of alkaloids, triterpenes, steroids, tannins and anthraquinones and can often be used for the production of synthetic drugs, modified from primary metabolites (Waterman, 1992).

The interaction of tannins (phenolic compound) is to prevent the absorption of proteins and alkaloids, due to the formation of irreversible complexes, or to promote the induction of enzymes such as CYP, accelerating the metabolism of drugs, resulting in low blood concentrations and, consequently, less therapeutic effect. In the case of oral contraceptives, there is a decrease in ethinyl estradiol by induction of CYP 3A4 (Williamson, 2001; Simões \& Schenkel, 2002;).

\section{Kava-kava (Piper methysticum Forster):}

Piper methysticum G. Forster is popularly known as kava-kava and belongs to the Piperaceae family. It is composed of: sugars, kavalactones, stigmasterol, flavocaines, bornyl-cinnamate, cinnamic acid, benzoic acid, mucilages, pyrones, 
tetrahydroyangonine, and about 3\% minerals, with potassium showing the most significant amount (Bilia et al., 2002; Cordeiro et al., 2005).

The use of kava-kava is due to its pharmacological activity on the central nervous system, being anxiolytic, anticonvulsant, sedative, anesthetic (local), analgesic and spamolytic, its mechanism of action is not known, but among its components the kavalactones, kavaína, diidrokavaína, metisticina, diidrometisticina stand out as the main responsible for this activity. There is no evidence of efficacy for its other uses, but it is used in traditional medicine to treat headaches, respiratory tract infections, wound healing, uterine inflammation and others (Bilia et al., 2002; Cordeiro et al., 2005).

The herbal medicines that contain Piper methysticum G. Forster extract have been used as an alternative for the treatment of anxiety and insomnia instead of benzodiazepines, because they have fewer adverse effects, such as dependence and cognitive disorders. The World Health Organization advises that this drug should not be taken for more than three months without medical advice, even within the prescribed dosage (Justo et al., 2008).

The kavalactones are components of Piper methysticum capable of inhibiting CYP3A4, an isoform of cytochrome P450, thus is responsible for the pharmacokinetic interaction with oral contraceptives, decreasing their safety and effectiveness. (Unger et al., 2002; Zou et al., 2004; Anke \& Ramzan, 2004; Coulter et al., 2007).

\section{Saw Palmetto (Serenoa repens):}

Serenoa repens Bartr. Smal. known as Saw Palmetto popularly is derived from the fruit of the Serenoa repens palm tree. It is composed of: fatty acids, carotenes, resin, steroids, oleic acid, tannins, flavonoids (mainly isoflavones) and polysaccharides (Dhariwala \& Ravikumar, 2019).

The herbal medicine of Saw Palmetto is a used for its multiple therapeutic actions, among them are the uses as a diuretic, expectorant, sedative, urinary symptoms and for the treatment of symptomatic benign prostatic hypertrophy, through liquid extracts, capsules and tablets (Bethesda, 2012).

The mechanism of action consists of the inhibition of 5 -alpha reductase, thus it exhibits a hormonal action opposite to that of testosterone. The interaction between saw palmetto and oral contraceptives is linked to its mechanism of action, because it interacts with estrogens that are present in hormone replacement therapies, and may decrease their effectiveness, in which case it is recommended to readjust the dose of contraceptives, due to its antiandrogenic and antiestrogenic effects, or even the suspension of use, being necessary the use of other methods of contraception for the prevention of unwanted pregnancy. Like soy, Saw Palmetto also has isoflavones in its composition, being active compounds pharmacologically responsible for interacting with hormone therapies, competing with estrogens for the estrogen receptor binding site (Dhariwala \& Ravikumar, 2019; Esteves et al., 2020).

\section{Sene (Cassia angustifolia vahl)}

Cassia angustifolia vahl, popularly known as sene, has its origin in India and Somalia. It is a stimulant and irritant type laxative, which increases the peristaltic activity of the intestine, having as its main site of action the intestinal wall and the direct stimulation of enteric nerve endings. Identified in its leaves are the chemical classes: fatty acids, alkaloids and phenolic compounds, such as anthraquinones, coumarins, flavonoids, saponins and tannins (Rodrigues et al., 2009).

Products that have anthraquinones in their composition should be avoided during pregnancy, since there is a risk of fetal loss due to increased blood flow to the uterus and induction of contractions (Rossato et al., 2012).

Sene decreases intestinal transit time (by the laxative action of the drug) and reduces the absorption of orally administered drugs. Therefore, the use of oral contraceptives concomitant with sene reduces its action due to the effect of intestinal transit on estrogen absorption (Organization, 2009). 


\section{Soybeans (Glycine max)}

Glycine max is a legume popularly known as Soybean. Its phytochemical compounds are important for the homeostasis of the organism, among them stands out the isoflavone, which is subdivided into four groups: aglycones, beta glycosides, glycosylated and malonylated glycosylated. It has a common phenolic structure, being the reason for the interaction with estrogenic receptors (Duranti, 2006).

Isoflavones are the active compounds responsible for the pharmacological action of this plant that has been used to prevent chronic-degenerative diseases, and to help treatments where there is a dependence on hormones, such as menopause and breast cancer (Bortolini, 2009).

Studies show that the estrogenic effect of Glycine max is not significant, being 1/1,000 to $1 / 100,000$, lower than the activity of estradiol, but in the presence of estrogen, soy ends up being an antagonist, competing with them for the binding site on estrogen receptors (Queiroz et al., 2006).

The use of soy concomitant with oral contraceptives interferes with their performance, because it changes their hormone levels. This association reduces the effectiveness and/or safety of contraceptives, increasing the adverse and toxic effects of estrogen derivatives (Silva \& Rocha, 2013; Brazil, 2016; N. C. de S. Silva et al., 2017).

\section{Final Considerations}

Oral hormonal contraceptives are the contraceptive method most used by women seeking to prevent unwanted pregnancy and other benefits, such as regularization of the menstrual cycle, colic reduction and acne. The change in women's profile, assuming their role as protagonists of their own lives over the last decades, especially in relation to sexuality, linked to the transition of society, the way of thinking, and the purpose of life in modern times has made the use of oral contraceptives more present in society, as well as the search for healthy lifestyles, adhering to natural products, consequently increasing the use of herbal medicines.

Despite the advance of allopathic medicine, the use of herbal medicines has become a practice present in the daily life of society because they are easily accessible and generally present fewer side effects. Consequently, these advantages are associated with the popular belief, without scientific foundation, that products of plant origin are not capable of posing health risks. Herbal medicines can be simple or compound used in phytotherapy, containing more than one plant species, according to the RDC No. 26 (05/13/2014).

Thus, the use of herbal medicines concomitant with oral contraceptives should not go unnoticed by health professionals when performing the anamnesis of a patient, especially pharmacists who are trained to identify drug interactions of herbal medicines. The efficacy and/or safety of these therapeutic classes depend on their correct and rational use, and it is extremely important that patients are oriented about their possible interactions resulting in the inefficacy of the chosen contraceptive. Thus, with knowledge and guidance, women can avoid the continuous and/or exacerbated use of herbal medicines, preventing an unplanned pregnancy.

Finally, in this literature review, scientific studies pertinent to drug interactions between herbal medicines and oral contraceptives were surveyed, but it is possible to notice that there is a great scarcity of recent studies on the subject due to the fact that it is not a practice to carry out this investigation.

\section{Acknowledgments}

The authors would like to thank Robson Valmiro for all his collaboration and help in translating this article. 


\section{References}

Aizpurua-Olaizola, O., Soydaner, U., Öztürk, E., Schibano, D., Simsir, Y., Navarro, P., Etxebarria, N., \& Usobiaga, A. (2016). Evolution of the Cannabinoid and Terpene Content during the Growth of Cannabis sativa Plants from Different Chemotypes. Journal of Natural Products, 79(2), 324-331. https://doi.org/10.1021/acs.jnatprod.5b00949

Almeida, A. P. F., \& Assis, M. M. (2017). Efeitos colaterais e alterações fisiológicas relacionadas ao uso contínuo de anticoncepcionais hormonais orais. Rev.Eletrôn.Atualiza Saúde, 5(5), 85-93. http://atualizarevista.com.br/wp-content/uploads/2017/01/efeitos-colaterais-e-alterações-fisiológicas-relacionadas-aouso-contínuo-de-anticoncepcionais-hormonais-orais-v-5-n-5.pdf

Anke, J., \& Ramzan, I. (2004). Pharmacokinetic and pharmacodynamic drug interactions with Kava (Piper methysticum Forst. f.). Journal of Ethnopharmacology, 93(2-3), 153-160. https://doi.org/10.1016/j.jep.2004.04.009

Bahamondes, L., Pinho, F., de Melo, N. R., Oliveira, E., \& Bahamondes, M. V. (2011). Fatores associados à descontinuação do u so de anticoncepcionais orais combinados. Revista Brasileira de Ginecologia e Obstetricia, 33(6), 303-309. https://doi.org/10.1590/S0100-72032011000600007

Bahis, S. C. (2001). Antidepressant herbal treatment. Jornal Brasileiro de Psiquiatria, 50(11-12), 389-396.

Barnes J. (2003). Pharmacovigilance of herbal medicines: a UK perspective. Drug Saf. https://doi.org/10.2165 / 00002018-200326120-00001

Barnes, J. (2010). Black cohosh. Journal of Primary Health Care, 2(1), 79-80. https://doi.org/10.1071/hc10079

Bethesda. (2012). Phenhyltoloxamine. LiverTox: Clinical and Research Information on Drug-Induced Liver Injury, Bookshelf http://www.ncbi.nlm.nih.gov/pubmed/31643176

Bilia, A. R., Bergonzi, M. C., Lazari, D., \& Vincieri, F. F. (2002). Characterization of commercial kava-kava herbal drug and herbal drug preparations by means of nuclear magnetic resonance spectroscopy. Journal of Agricultural and Food Chemistry, 50(18), 5016-5025. https://doi.org/10.1021/jf020049j

Biondi, D. M., Rocco, C., \& Ruberto, G. (2005). Dihydrostilbene derivatives from Glycyrrhiza glabra leaves. Journal of Natural Products, 68(7), 1099-1102. https://doi.org/10.1021/np050034q

Bortolini, C. E. (2009). Efeitos Da Administração De Fitoterápico Contendo Glycine Max (L.) Merr Durante O Período De Organogênese Em Ratas Wistar. Universidade Federal Do Rio Grande Do Sul Faculdade De Veterinária Programa De Pós-Graduação Em Ciências Veterináriasprograma De Pós-Graduação Em Ciências Veterinárias, 78. Https://Www.Lume.Ufrgs.Br/Bitstream/Handle/10183/16327/000702157.Pdf?Sequence=1

Brasil. (2004). Resolução-rdc no 48, de 16 de março de 2004. Ministério da Saúde. Agência Nacional de Vigilância Sanitária. 2446-4775. http://revistafitos.far.fiocruz.br/index.php/revista-fitos/article/view/28

Brasil. (2006). Política Nacional de Plantas Medicinais e Fitoterápicos. https://bvsms.saude.gov.br/bvs/publicacoes/politica_nacional_fitoterapicos.pdf

Brasil. (2010). Farmacopeia Brasileira. Agência Nacional De Vigilância Sanitária SIA, 5 Edição. https://www.gov.br/agricultura/ptbr/assuntos/inspecao/produtos-vegetal/legislacao-1/biblioteca-de-normas-vinhos-e-bebidas/farmacopeia_volume-1_2010.pdf

Brasil. (2014). RDC N ${ }^{\circ}$ 26, de 13 de maio de 2014.34. https://bvsms.saude.gov.br/bvs/saudelegis/anvisa/2014/rdc0026_13_05_2014.pdf

Brasil. (2015). Política Nacional de Práticas Integrativas e Complementares no SUS. In Diário da República, 2.a série - n.o 102 (27-05-2015). https://bvsms.saude.gov.br/bvs/publicacoes/politica_nacional_praticas_integrativas_complementares_2ed.pdf

Brasil. (2016). Memento Fitoterápico da Farmacopeia Brasileira. Agência Nacional de Vigilância Sanitária, 1-114. https://www.gov.br/anvisa/ptbr/assuntos/farmacopeia/memento-fitoterapico/memento-fitoterapico.pdf/view

Brasil, N. (2001). Self medication. Revista Da Associação Médica Brasileira (1992), 47(4), 269-270. https://doi.org/10.1590/s0104-42302001000400001

Brito, M. B., Nobre, F., \& Vieira, C. S. (2011). Hormonal contraception and cardiovascular system. Arquivos Brasileiros de Cardiologia, 96(4). https://doi.org/10.1590/S0066-782X2011005000022

Cook, B G.; Pengelly, BC; Brown, S.; Donnelly, JR; Eagles, D.; Franco, A.; Hanson, J.; Mullen, B.; Partridge, I.; Peters, M.; \& Schultze-Kraft, R. (2005). Medicago sativa. In Tropical Forages: uma ferramenta de seleção interativa. http://www.tropicalforages.info/

Cordeiro, C. H. G., Chung, M. C., \& Sacramento, L. V. S. do. (2005). Interações medicamentosas de fitoterápicos e fármacos: Hypericum perforatum e Piper methysticum. Revista Brasileira de Farmacognosia, 15(3), 272-278. https://doi.org/10.1590/s0102-695x2005000300019

Coulter, D., Tamayo, C., Sotheeswaran, S., \& Ulbricht, C. (2007). Assessment of the risk of hepatotoxicity with kava products. WHO Library Cataloguing-inPublication Data, 1-82. https://apps.who.int/iris/bitstream/handle/10665/43630/9789241595261_eng.pdf?sequence=1\&isAllowed=y

CRF-SP. (2019). Medicinal Plants and Herbal Medicines. $4^{\circ}$ Edição, 72. http://www.crfsp.org.br/images/cartilhas/PlantasMedicinais.pdf

Dhariwala, M. Y., \& Ravikumar, P. (2019). An overview of herbal alternatives in androgenetic alopecia. Journal of Cosmetic Dermatology, 18(4), 966-975. https://doi.org/10.1111/jocd.12930

Duranti, M. (2006). Grain legume proteins and nutraceutical properties. Fitoterapia, 77(2), 67-82. https://doi.org/10.1016/j.fitote.2005.11.008

Esteves, M. H. S., Leite, B. de C., Vargas, A. M. P., Franco, A. J., \& Diniz, R. S. (2020). Principais Interações No Uso De Medicamentos Fitoterápicos. Pesquisa, Produção e Difusão de Conhecimentos Nas Ciências Farmacêuticas 2, 173-178. https://doi.org/10.22533/at.ed.64820201118 
Farias, M. R., Leite, S. N., Tavares, N. U. L., Oliveira, M. A., Arrais, P. S. D., Bertoldi, A. D., Pizzol, T. da S. D., Luiza, V. L., Ramos, L. R., \& Mengue, S. S. (2016). Use of and access to oral and injectable contraceptives in Brazil. Revista de Saude Publica, 50(2). https://doi.org/10.1590/S1518-8787.2016050006176

Fernandes, A. V. F. (2011). Ginseng (Panax ginseng): Mito ou Verdade Científica? 57.

Greeson, J. M., Sanford, B., \& Monti, D. A. (2001). St. John's wort (Hypericum perforatum): A review of the current pharmacological, toxicological, and clinical literature. Psychopharmacology, 153(4), 402-414. https://doi.org/10.1007/s002130000625

Hall, S. D., Wang, Z., Huang, S. M., Hamman, M. A., Vasavada, N., Adigun, A. Q., Hilligoss, J. K., Miller, M., \& Gorski, J. C. (2003). The interaction between St John's wort and an oral contraceptive. Clinical Pharmacology and Therapeutics, 74(6), 525-535. https://doi.org/10.1016/j.clpt.2003.08.009

Hanan Abramovici, P. D., \& Sophie-Anne Lamour, Ph.D. \& George Mammen, P. D. (2018). Information for Health Care. https://www.canada.ca/en/healthcanada/services/drugs-medication/cannabis/information-medical-practitioners/information-health-care-professionals-cannabis-cannabinoids.html\#authorship

Huntley, A., \& Ernst, E. (2003). A systematic review of the safety of black cohosh. Menopause, 10(1), 58-64. https://doi.org/10.1097/00042192-20031001000010

Izzo, A. A., \& Ernst, E. (2009). Interactions between herbal medicines and prescribed drugs: An updated systematic review. Drugs, 69(13), 1777-1798. https://doi.org/10.2165/11317010-000000000-00000

Justo, S. C., Silva, C. M., \& Silva, C. M. (2008). Piper Methysticum G. Forster (Kava-Kava): Uma Abordagem Geral. Revista Eletrônica de Farmácia, 5(1). https://doi.org/10.5216/ref.v5i1.4617

Lemus Rodríguez, Z.; García Negrín, M. M.; \& Chong Quesada, A. (2003). Alfalfe: an excellence remineralizing element in the vegetable world. Medisan. https://pesquisa.bvsalud.org/portal/resource/pt/cum-26604

Lewis, M. M., Yang, Y., Wasilewski, E., Clarke, H. A., \& Kotra, L. P. (2017). Chemical Profiling of Medical Cannabis Extracts. ACS Omega, 2(9), 6091-6103. https://doi.org/10.1021/acsomega.7b00996

Lim, T. K. (2016). Glycyrrhiza glabra. In Edible Medicinal and Non-Medicinal Plants (pp. 354-457). Springer Netherlands. https://doi.org/10.1007/978-94-0177276-1_18

Lucas, C. J., Galettis, P., \& Schneider, J. (2018). The pharmacokinetics and the pharmacodynamics of cannabinoids. British Journal of Clinical Pharmacology, 84(11), 2477-2482. https://doi.org/10.1111/bcp.13710

Murphy, P. A., Kern, S. E., Stanczyk, F. Z., \& Westhoff, C. L. (2005). Interaction of St. John's Wort with oral contraceptives: Effects on the pharmacokinetics of norethindrone and ethinyl estradiol, ovarian activity and breakthrough bleeding. Contraception, 71(6), 402-408. https://doi.org/10.1016/j.contraception.2004.11.004

Nassiri Asl, M., \& Hosseinzadeh, H. (2008). Review of pharmacological effects of glycyrrhiza sp. and its bioactive compounds. Phytotherapy Research, 22(6), 709-724. https://doi.org/10.1002/ptr.2362

Organization, W. H. (2009). WHO Monographs on Selected Medicinal Plants. World Health Organization, 4, 390. http://books.google.com/books?hl=en\&amp;lr=\&amp;id=qWP4aG-wXAQC\&amp;oi=fnd\&amp;pg=PR5\&am p;dq=WHO+monogra phs+on+select ed+medic inal+plants\&amp;ots=RJt-DVSuko\&amp;sig=-WVSUOWRMzrFVcq1wUaLCfVkaHE

Pereira, C. D. (2015). Medicago sativa em homeopatia: revisão de literatura. Centro Alpha De Ensino Associação Paulista De Homeopatia, 66. http://homeopatia.bvs.br/lildbi/docsonline/get.php?id=044

Pfrunder, A., Schiesser, M., Gerber, S., Haschke, M., Bitzer, J., \& Drewe, J. (2003). Interaction of St John's wort with low-dose oral contraceptive therapy: A randomized controlled trial. British Journal of Clinical Pharmacology, 56(6), 683-690. https://doi.org/10.1046/j.1365-2125.2003.02005.x

Piao, X. M., Huo, Y., Kang, J. P., Mathiyalagan, R., Zhang, H., Yang, D. U., Kim, M., Yang, D. C., Kang, S. C., \& Wang, Y. P. (2020). Diversity of ginsenoside profiles produced by various processing technologies. Molecules, 25(19). https://doi.org/10.3390/molecules25194390

Queiroz, S. C. N., Nogueira, R. T., \& Scramin, S. (2006). Importância dos fitoestrógenos, presentes na soja, para a saúde humana. 4. https://www.agencia.cnptia.embrapa.br/recursos/Queiroz_Nogueira_Scramin_importanciaID-5nX98pWTxk.pdf

Rathke, A. F., Poester, D., \& Lorenzatto, J. F. (2001). Contracepção hormonal contendo apenas progesterona. Adolesc. Latinoam, 2(2), 90-96. http://redece.org/Contracepcaohormonal2014.pdf

Rätz, A. E., Von Moos, M., \& Drewe, J. (2001). Johanniskraut: Ein phytopharmakon mit potentiell gefährlichen interaktionen. Praxis, 90(19), 843-849.

Rodrigues, I. M. C., Souza Filho, A. P. S., \& Ferreira, F. A. (2009). Phytochemical study of Senna alata using two methodologies. Planta Daninha, 27(3), 507513. https://doi.org/10.1590/s0100-83582009000300011

Rossato, A. E., Pierini, M. M., Amaral, P. A., Santos, R. R., \& Citadini-Zanette, V. (2012). Fitoterapia racional: aspectos taxonômicos, agroecológicos, etnobotânicos e terapêuticos. In Fitoterapia racional. http://scholar.google.com/scholar?hl=en\&btnG=Search\&q=intitle:Fitoterapia+Racional+:\#0

Schwarz, U. I., Büschel, B., \& Kirch, W. (2003). Unwanted pregnancy on self-medication with St John's wort despite hormonal contraception. British Journal of Clinical Pharmacology, 55(1), 112-113. https://doi.org/10.1046/j.1365-2125.2003.01716.x

Shahidi, F.; \& Ho, C.-T. (2005). Phenolic compounds in foods and natural health products. American Chemical Society.

Shahidi, F.; \& Naczk, M. (2003). Phenolics in foods and nutraceuticals. Boca Raton. 
Research, Society and Development, v. 10, n. 13, e372101321331, 2021

(CC BY 4.0) | ISSN 2525-3409 | DOI: http://dx.doi.org/10.33448/rsd-v10i13.21331

Silva, A. G., Brandão, A. B., Cacciari, R. S., \& Soares, W. H. (2009). Advances on the elucidation of mechanisms of action of Cimicifuga racemosa (L.) Nutt. in climacteric symptoms. Revista Brasileira de Plantas Medicinais, 11(4), 455-464. https://doi.org/10.1590/s1516-05722009000400015

Silva, L. M. da S., \& Rocha, M. R. (2013). Interações medicamentosas dos anticoncepcionais com outros fármacos. Revista Oswaldo Cruz, 11. http://revista.oswaldocruz.br/Content/pdf/Edicao_09_SILVA_Luma_Meirelles_da_Silva_-_ROCHA_Marcia_Rocha.pdf

Silva, N. C. de S., Thomaz, A. P. S., Melo, J. A., \& Martins, S. B. M. (2017). Interações Medicamentosas com Contraceptivos Hormonais Orais. 1-7. http://co.unicaen.com.br:89/periodicos/index.php/UNICA/article/view/57

Simões, C. M. O., \& Schenkel, E. P. (2002). A pesquisa e a produção brasileira de medicamentos a partir de plantas medicinais: a necessária interação da indústria com a academia. Revista Brasileira de Farmacognosia, 12(1), 35-40. https://doi.org/10.1590/s0102-695x2002000100005

Souza, A. A. F. de, Silva, A. F. M. da, Abreu, L. R. de, Silva, T. F. da, Greco, G., Santos, S. da S., \& Gonzaga, R. V. (2021). Medicinal uses of Cannabis sp. Research, Society and Development, 10(7), e58010716930. https://doi.org/10.33448/rsd-v10i7.16930

Taiz, L.; \& Zeiger, E. (2006). Plant physiology. Sinauer Associates Inc. (4a ed.).

Unger, M., Holzgrabe, U., Jacobsen, W., Cummins, C., \& Benet, L. Z. (2002). Inhibition of cytochrome P450 3A4 by extracts and kavalactones of Piper methysticum (Kava-Kava). Planta Medica, 68(12), 1055-1058. https://doi.org/10.1055/s-2002-36360

Vibha, J. B., Choudhary, K., Singh, M., \& Shekhawat, N. S. (2009). A Study on Pharmacokinetics and Therapeutic Efficacy of Glycyrrhiza glabra: A Miracle Medicinal Herb. Botany Research International, 2(3), 157-163.

Vincent, A., \& Fitzpatrick, L. A. (2000). Soy isoflavones: Are they useful in menopause? Mayo Clinic Proceedings, 75(11), 1174-1184. https://doi.org/10.4065/75.11.1174

Waterman, P. G. (1992). Roles for secondary metabolites in plants. Ciba Foundation Symposium, 171. https://doi.org/10.1002/9780470514344.ch15

Will-Shahab, L., Bauer, S., Kunter, U., Roots, I., \& Brattström, A. (2009). St John's wort extract (Ze 117) does not alter the pharmacokinetics of a low-dose oral contraceptive. European Journal of Clinical Pharmacology, 65(3), 287-294. https://doi.org/10.1007/s00228-008-0587-2

Williamson, E. M. (2001). Synergy and other interactions in phytomedicines. Phytomedicine, 8(5), 401-409. https://doi.org/10.1078/0944-7113-00060

Wittschier, N., Faller, G., \& Hensel, A. (2009). Aqueous extracts and polysaccharides from Liquorice roots (Glycyrrhiza glabra L.) inhibit adhesion of Helicobacter pylori to human gastric mucosa. Journal of Ethnopharmacology, 125(2), 218-223. https://doi.org/10.1016/j.jep.2009.07.009

Wobser, R. W., \& Pellegrini, M. V. (2018). Black Cohosh (Actaea Racemosa, Black Bugbane, Black Snakeroot, Fairy Candle). StatPearls. http://www.ncbi.nlm.nih.gov/pubmed/29261886

World Health Organization. (2002). Herba Andrographidis. In WHO monographs on selected medicinal plants, 2, 12-24.

World Health Organization Geneva. (2017). Depression and Other Common Mental Disorders: Global Health Estimates. World Health Organization, 24. https://apps.who.int/iris/bitstream/handle/10665/254610/W?sequence=1

Zou, L., Henderson, G. L., Harkey, M. R., Sakai, Y., \& Li, A. (2004). Effects of Kava (Kava-kava, 'Awa, Yaqona, Piper methysticum) on c-DNA-expressed cytochrome P450 enzymes and human cryopreserved hepatocytes. Phytomedicine, 11(4), 285-294. https://doi.org/10.1078/0944711041495263 